\title{
EXTL2 wt Allele
}

National Cancer Institute

\section{Source}

National Cancer Institute. EXTL2 wt Allele. NCI Thesaurus. Code C50963.

Human EXT L2 wild-type allele is located within 1p21 and is approximately $24 \mathrm{~kb}$ in length.

This allele, which encodes exostosin-like 2 protein, plays a role in the initiation of heparin/heparin sulfate biosynthesis. 